\title{
Nemzeti ökoszisztéma-szolgáltatás térképezés és értékelés, avagy a természetvédelem országos programja
}

\author{
Kovács-Hostyánszki Anikó ${ }^{1}$, Bereczki Krisztina ${ }^{1}$, Czúcz Bálint ${ }^{1}$, \\ Fabók Veronika $^{1}$, Fodor Lívia ${ }^{2}$, Kalóczkai Ágnes ${ }^{1}$, Kiss Márton ${ }^{1,3}$, \\ Koncz Péter ${ }^{1,4}$, Kovács Eszter ${ }^{5}$, Rezneki Rita ${ }^{1,4}$, Tanács Eszter ${ }^{1}$, \\ Török Katalin ${ }^{1}$, Vári Ágnes ${ }^{1,6}$, Zölei Anikó1 ${ }^{1}$, Zsembery Zita ${ }^{2}$ \\ ${ }^{1}$ Ökológiai Kutatóközpont, Ökológiai és Botanikai Intézet, \\ 2163 Vácrátót, Alkotmány u. 2-4., \\ ${ }^{2}$ Agrárminisztérium, Természetmegörzési Főosztály, \\ 1055 Budapest, Kossuth Lajos tér 11. \\ ${ }^{3}$ Szegedi Tudományegyetem, Éghajlattani és Tájföldrajzi Tanszék, \\ 6722 Szeged, Egyetem u. 2. \\ ${ }^{4}$ Duna-Ipoly Nemzeti Park Igazgatóság, 1121 Budapest, Költő u 21. \\ ${ }^{5}$ Szent István Egyetem, Természetvédelmi és Tájgazdálkodási Intézet, \\ 2100 Gödöllö, Páter Károly u. 1. \\ ${ }^{6}$ Ökológiai Kutatóközpont, ,, GINOP Ökoszisztémák fenntartható müködtetése” \\ Kutatócsoport, 8237 Tihany, Klebelsberg Kuno u. 3.

\section{E-mail:kovacs.aniko@okologia.mta.hu}

Összefoglaló: Az Európai Unió 2020-ig megvalósítandó Biodiverzitás Stratégiájának egyik fő célkitüzése az ökoszisztéma-szolgáltatások (ÖSz-ek) minél teljesebb megörzése és helyreállítása. Ennek érdekében a tagországok számára elöírják, hogy térképezzék és értékeljék a területükön található ökoszisztémák állapotát (ÖÁ), valamint az általuk nyújtott ÖSz-ek helyzetét és gazdasági értékét. Magyarországon a 2016 őszén indult, Agrárminisztérium által koordinált KEHOP-4.3.0VEKOP-15-2016-00001 számú kiemelt projekt keretében az „Ökoszisztéma-szolgáltatások” fejlesztési elem egyik fő feladata a hazai viszonyok között kiemelt fontossággal bíró ÖSz-ek országos térképezése és értékelése (Nemzeti Ökoszisztéma-szolgáltatás Térképezés és Értékelés; NÖSZTÉP). Az értékelés az ún. kaszkád-modell mentén végig halad az ÖSz-eket meghatározó ÖÁ jellemzőktől, az ÖSz kapacitásokon és az ebből ténylegesen igénybe vett szolgáltatásokon át az emberi jóllét fenntartásában vagy növelésében játszott szerepükig. A projekt eredményei a tervek szerint segítik majd a természeti tőkénkkel való fenntartható gazdálkodást, a zöldinfrastruktúra-hálózat fejlesztését, az egyes ágazatok közti hatékonyabb kommunikációt és a természetvédelmi és más ágazati döntéshozatalt.

Kulcsszavak: Biodiverzitás Stratégia, fenntartható használat, jóllét, kapacitás, kaszkád-modell, MAES, ökoszisztéma állapot, zöld infrastruktúra 


\section{Bevezetés}

Miután a Millenniumi Ökoszisztéma Értékelés (Millennium Ecosystem Assessment - MEA) az elmúlt évtizedben ráirányította a figyelmet a természetes élőhelyek degradálódásának gyors ütemére és a természet emberi jólléthez való hozzájárulásának fontosságára (MEA 2003, 2005), az ökoszisztéma-szolgáltatások (ÖSz-ek) fogalma beépült a nemzetközi szakpolitikába és az Európai Unió (EU) természetvédelemre vonatkozó intézkedéseinek, célkitüzésének központi elemévé vált (Kovács 2014). ÖSz-ek alatt azokat a kézzelfogható és kézzel nem fogható javakat (termékeket és szolgáltatásokat) értjük, amelyeket az ökológiai rendszer természetes vagy átalakított formájában nyújt az emberek számára, így növelve a társadalom és tagjainak jóllétét (Kelemen 2013). Az EU 2020-ig megvalósítandó Biodiverzitás Stratégiájának egyik fö célkitűzése az ÖSz-ek minél teljesebb megőrzése és helyreállítása. Ennek érdekében a Biodiverzitás Stratégia 2. célkitűzésének 5. intézkedése előírja az EU tagországai számára, hogy térképezzék és értékeljék a területükön található ökoszisztémák állapotát (ÖÁ), valamint az általuk nyújtott ÖSz-ek helyzetét, gazdasági értékét, továbbá törekedjenek arra, hogy 2020-ig ezek az értékek beépüljenek az uniós és nemzeti szintủ számviteli és jelentéstételi rendszerekbe (EC 2013). Az ökoszisztémák és szolgáltatásaik térképezésének, értékelésének elősegítésére az EU egy munkacsoportot állított fel (Working Group on Mapping and Assessment of Ecosystems and their Services - MAES WG), amelynek feladata, hogy szakmai háttéranyagokkal, esettanulmányok, jó gyakorlati példák bemutatásával, valamint módszertani ajánlásokkal segítse a tagországokat (Maes et al. 2013, 2014, 2018).

Az ökoszisztémák és szolgáltatásaik térképezésének, értékelésének elősegítésére és a fentebbi célok teljesítésére indult az Agrárminisztérium Természetmegőrzési Főosztálya (AM TMF) által koordinált „A közösségi jelentőségű természeti értékek hosszú távú megőrzését és fejlesztését, valamint az EU Biológiai Sokféleség Stratégia 2020 célkitüzéseinek hazai szintủ megvalósítását megalapozó stratégiai vizsgálatok" címü projekt ${ }^{1}$. A természetvédelem ezen országos programjának “Ökoszisztéma-szolgáltatások" (Nemzeti Ökoszisztéma-szolgáltatás Térképezés és Értékelés; NÖSZTÉP) nevű projekteleme többek között egyes, a hazai viszonyok között kiemelt fontossággal bíró ÖSz-ek országos térképezését és értékelését tüzte ki céljául. A program megvalósítása így hozzájárul a biológiai sokféleség megőrzését célzó, 2020-ig szóló nemzeti és európai uniós biodiverzitás stratégia kitűzött céljainak megvalósításához. A projekt konzorciumi partnerei az Ökológiai Kutatóközpont (ÖK), a Lechner Tudásközpont, az Agrártudományi Kutatóközpont, Talajtani és Agrokémiai Intézet, a NAIK Agrárgazdasági Kutatóintézet

1 http://www.termeszetvedelem.hu/kehop-430-15-2016-00001 
és a projektkoordinátor AM TMF. Az értékelés az érintett legfontosabb ágazatok és tudományágak szakértőinek bevonásával valósul meg. A 2020 év végéig tartó projekt megalapozása 2016 öszén indult, és egy előkészítő szakaszt követően 2017 öszén fordult a megvalósítási szakaszba.

Cikkünk célja a NÖSZTÉP felépítésének, módszertanának és az előkészítő szakasz eredményeinek bemutatása az ÖSz értékelésre vonatkozóan. Az előkészítő szakasz során készült el a projekt részletes célrendszerének kialakítása, a munka szakmai megalapozása, koncepcionális hátterének lefektetése, érintettek elemzése és ehhez kapcsolódó bevonási stratégia, az ÖSz-ek nemzetközi kategórarendszerének hazai adaptációja (CICES-HU), az ÖSz-ek priorizálása és elemzésre kiválasztása. Mindezek alapján megtörtént a projektelem strukturális kiépítése és a tematikus munkatervek kidolgozása.

\section{A NÖSZTÉP szerkezeti felépitése és föbb feladatai}

A NÖSZTÉP ÖSz értékelési és térképezési feladatai több munkacsoportba szerveződnek (NÖSZTÉP Munkacsoportok):

- A Részvételi Munkacsoport készítette elő az értékelendő ÖSz-ek listáját egy érintett elemzés (az ÖSz-ek által érintett ágazatok, szervezetek és kapcsolatrendszerük feltárása), majd különböző ágazati szakértők körében végzett interjúk segítségével. A megvalósítási szakaszban segítik a megfelelő szakértők bevonását az értékelési folyamatba, irányítják a jólléti értékelést és az ÖSz értékelésekre alapuló jövőképalkotási folyamatot.

- Az Ökoszisztéma Térképező és Ökoszisztéma Állapot Értékelő és Térképező Munkacsoport az általános, országos ökoszisztéma állapot térképek és az országos Ökoszisztéma alaptérkép elkészítését koordinálja a NÖSZTÉP szakmai szempontjai szerint, az ÖK és a Lechner Tudásközpont szakértőinek részvételével. Ezen raszteres, $20 \times 20$ méteres térbeli felbontású Ökoszisztéma alaptérképre (lásd ebben a számban Tanács és Belényesi et al. 2019) épül az ÖSz-ek térképezése, a lehető legnagyobb megvalósítható részletességgel. Ez a felbontás azonban csak ábrázolási felbontásként értelmezhető, mivel a legtöbb forrásadatbázis térbeli pontossága nem éri el ezt a részletességet. Az általános állapottérképek a hagyományos értelemben vett ökoszisztéma állapotot (természetesség, ökoszisztéma egészség, ökoszisztéma integritás) jellemzik, ökoszisztéma típusonként eltérő indikátorok felhasználásával. 
- Az ÖSz Értékelő és Térképező Munkacsoport az ÖSz értékelés tágabb, szakmai keretének, hátterének biztosításáért felel, természettudományi és társadalomtudományi szakértőket bevonva. Az adott ÖSz térképezésének és modellezésének előkészítéséhez a munkacsoport áttekinti az adott szolgáltatás térképezésének módszereit, lehetséges és sikeresen alkalmazott indikátorait a koncepcionális háttérként használt kaszkád-modell különböző szintjein (lásd. alább), különös tekintettel a megvalósult nemzeti értékelésekre, illetve felméri az ehhez használható, elérhető adatokat. A munkacsoport egy-egy tagja koordinálja, követi és segíti végig egy-egy szakértői munkacsoport (SZMCS, lásd lentebb) munkáját mint SzMCs vezető, képviseli abban az ÖSz értékelés és térképezés szakmai szempontjait, miközben dokumentálja a teljes folyamatot. Kapcsolatot tart a Lechner Tudásközponttal az ÖSz-ek térképi megjelenítése és a partnerekkel a folyamat előrehaladása kapcsán.

- A NÖSZTÉP munkacsoportok munkáját az ÖK, magát a projektet az AM TMF koordinálja és felügyeli. Ezen túl tanácsadó szervként az elkészülő jelentéseket, tanulmányokat nagyobb munkafázisonként a Vezetői Szakértői Panel (VSZP) tekinti át és véleményezi. Ennek tagjai a hazai érintett ágazatok szakértő képviselői, kutatók, civil szervezetek szakértői. A VSZP tudományos-szakmapolitikai platform, amely a szakértők részvételével segíti az értékelési folyamat előrehaladását, valamint az eredmények ágazati integrálását.

\section{Az ökoszisztéma-szolgáltatások kiválasztása}

A NÖSZTÉP során értékelésre és térképezésre javasolt Ösz-ek listájának összeállítása több lépcsőben zajló szakmai feladat volt. A MAES módszertani ajánlások között szerepel az ÖSz-ok osztályozására, csoportosítására az Ökoszisztéma-szolgáltatások Közös Nemzetközi Osztályozási rendszerének (Common International Classification of Ecosystem Services - CICES, Haines-Young \& Potschin 2013) alkalmazása, melyet a NÖSZTÉP is adaptált. Ehhez első lépcsőben elkészítettük a CICES 4.3 magyar nyelvü változatát (CICES-HU), mely tartalmazza az eredeti kategóriarendszer minden elemét, kivéve a hazánkban nem releváns, tengeri ökoszisztémákhoz kötődő szolgáltatásokat. A CICES hierarchikus rendszer, amely a szolgáltatások három fő típusát különbözteti meg: ellátó, szabályozó és fenntartó, valamint kulturális szolgáltatások. Az ellátó szolgáltatások közé a társadalom számára közvetlen hasznot nyújtó anyagi javak sorolhatók (tápanyagok, nyersanyagok, állati és növényi energiaforrások). A szabályozó és fenntartó szolgáltatások 
közé tartoznak mindazon felszíni vagy felszín alatti természeti folyamatok, melyek biztosítják az ökoszisztémák müködésének egyensúlyát (pl. talaj, víz, légkör állapotainak, folyamatainak szabályozása, beporzás, biológiai védelem). Kulturális szolgáltatásoknak tekinthetjük azokat a nem materiális szolgáltatásokat, amelyeket az emberek a természetből meríthetnek (pl. rekreáció, kikapcsolódás a természetben, spirituális gazdagodás).

A NÖSZTÉP előkészítő évében (2017) különböző ágazatok (természetvédelem, erdészet, vadászat, mezőgazdaság, halászat, vízgazdálkodás, területi tervezés, kereskedelem, turizmus, ipar - adminisztratív szervek, állami és magánszektor, civil szervezetek, kutatóintézetek) képviselői körében végzett 23 interjú alapján előzetesen felmerült 73 ÖSz példát (előzetes ÖSz lista) a CICES-HU szerint kategorizáltuk. Ezt követően az előzetes ÖSz-listát négy priorizáló workshop keretében, az alábbi élőhely kategóriákban rangsoroltak a bevont szakértők: erdők és faültetvények, vizek és vizes élőhelyek, lakott területek, gyepek és mezőgazdasági ökoszisztémák. Utóbbi kettőre ugyanazon mühelymunka keretein belül, de külön priorizálták a szakértők az ÖSz-eket. Az élőhelykategóriák kialakításakor a projektben alkalmazott módszertant alapvetően meghatározó MAES-folyamat szakmai anyagaiban használt definíciókra támaszkodtunk (Maes et al. 2014). A felállított átfogó kategóriák elsősorban a priorizálás céljait szolgálták, az értékelési és térképezési folyamatban nagyrészt részletesebb élőhelykategóriákkal dolgozunk.

A mühelymunkákon a főbb élőhelykategóriák mentén történő priorizálási munka lehetővé tette az adott élőhelyet ismerö, kezelö, kutató szakértők szélesebb körének (alkalmanként 8-14 fö) bevonását és az ÖSz-ek ezáltal alaposabb és többszempontú priorizálását. A résztvevők egy elöpriorizálás keretében már a mühelymunkát megelőzően pontozták az ÖSz-okat aszerint, hogy milyen fontosnak tartják társadalmilag az adott élőhely egyes szolgáltatásainak a hosszú távú fennmaradását, azaz, hogy szerintük milyen prioritást élvezzenek az egyes szolgáltatások az értékelés, térképezés során. Az előpriorizálásra építve, közös diszkusszióval a mühelymunkák célja élőhelyenként a 8-10 legfontosabbnak tartott ÖSz kiválasztása volt.

A priorizáló mủhelymunkák eredményét szintetizálva a NÖSZTÉP ÖSz-ek értékeléséért és térképezéséért felelös munkacsoport javaslatot tett az értékelésre és térképezésre szánt ÖSz-ek körére, melyet a projektpartnerekkel és a VSZP-vel megvitatott. Ennek eredményeként a következő ÖSz-ek értékelését és térképezését tüzte ki célul a NÖSZTÉP: 
I. Ellátó ÖSz-ek:

1. Agrárökoszisztémákban termesztett növények (szántóföldi növénytermesztés, zöldségtermesztés, gyümölcs- és szőlőtermesztés)

2. Tenyésztett állatok és termékeik (legelő és istállózó állattartás)

II. Szabályozó és fenntartó ÖSz-ek:

3. Növényi energiaforrások (növényi részek energianyerés céljára történő hasznosítása a tüzifa és a szántóföldi melléktermékek példáján)*

4. Szürés/tisztítás/megkötés/akkumuláció az ökoszisztémák által (biofizikai szürő, megkötő, tisztító folyamatok a talajban és vízben; kémiai és porszennyezés ülepedésének számítása lakott területeken)

5. Felszíni degradáció elleni védelem (víz általi talajerózióval szembeni védelem természetes vagy ültetett vegetáció által)

6. Hidrológiai ciklus és vízáramlás szabályozása (,,aszályvédelmi” funkció, a síkvidéki tájak vízmegtartó-képessége)

7. Árvízi kockázat-csökkentés és csapadékvíz-gazdálkodás (folyami árvíz elleni védelem az árterek mérséklő funkciója által síkvidéken; víz visszatartása, lefolyás mérséklése dombvidéken; lakott területeken extrém csapadékesemények víztöbbletének tározódása a fák levélfelületén)

8. Állati beporzás (vad- és háziméhek általi virágbeporzás (pollináció))

9. Éghajlat-szabályozás az üvegházhatású gázok koncentrációjának csökkentésével (üvegházhatású gázok mérlege, $\mathrm{CO}_{2}$ megkötés)

10. Mikroklíma szabályozás (a lakott területen kívüli és belüli mikroklíma szabályozása, utóbbi esetében a fák hatása az extrém nyári hőstressz mérséklésében)

III. Kulturális ÖSz-ek:

11. A természet rekreációs célú használata (gyalogos természetjárás)

12. Örökség (a természettel kapcsolatos tudás, tevékenység, normák összessége és identitás a gombászás példáján)

A szabályozó és fenntartó szolgáltatások között eredetileg kiválasztásra került a vizuális, zaj- és szaghatások szürése és mérséklésre, ennek értékelésére azonban a rendelkezésre álló módszertanok és az adatok hiánya, valamint a kevés elérhető szakértő miatt nem került sor.

* Erratum: A növényi energiaforrások hibásan került besorolásra, helyesen az I. Ellátó ökoszisztéma-szolgáltatások közé sorolandó. 


\section{Az ökoszisztéma-szolgáltatás értékelés módszertanának áttekintése}

A priorizálás során kiválasztott ÖSz-ek értékelése és térképezése a NÖSZTÉP megvalósítási szakaszának (2018-2020) egyik fő feladata. A munka fontos, kezdeti lépése volt ezen szakaszban az ökológiai folyamatok és szolgáltatások pontosítása. Az előkészítő év során elöállt ÖSz lista ugyanis csak átfogó (alapvetően a CICES-t követő) kategóriákat tartalmazott, ugyanakkor a térképezéshez és értékeléshez szükség volt a szolgáltatások és az azokat megalapozó ökológiai folyamatok megállapítására, pontosítására (a fenti listában zárójelben már ezen pontosított célterületek olvashatók minden kiválasztott ÖSz esetében).

Az értékelésben használt, alább bemutatott modellalkotáshoz szükséges paraméterek meghatározása szakértői segítséget, az adott szolgáltatások mélyebb ismeretét igényli, felhasználói, gazdasági, kezelési oldalról is a természettudományos, ökológiai ismeretek mellett. Ennek érdekében a megvalósítási szakasz első ütemében szakértői munkacsoportok (SZMCS) alakultak, amelyek egy vagy több, egymáshoz kapcsolódó ÖSz-re koncentrálnak, az alábbiak szerint (zárójelben a fent felsorolt ÖSz-ek sorszáma látható):

- Élelmiszertermelés SZMCS $(1,2)$

- Pollináció SZMCS (8)

- Klíma és Energia SZMCS $(3,9,10)$

- Hidrológia SZMCS $(4,5,6,7)$

- Városi SZMCS $(4,7,10)$

- Kulturális SZMCS $(11,12)$

Egyes ÖSz-ek így több SZMCS-ben, tematikai szempontok és érvényesülésük helye szerint bontva jelennek meg. Így például a mikroklíma szabályozást a Klíma és Energia SZMCS-ben táji léptékben, míg a Városi SZMCS-ben települési környezetben értékeljük. A szürési folyamatok közül a talajban és vízben megvalósuló szennyező anyag szürést a Hidrológia, a levegőt szennyező anyagok megkötését a Városi SZMCS vizsgálja.

Az értékelés során az alapvető elméleti keretrendszert a kaszkád-modell jelenti (Haines-Young \& Potschin 2010, Kovács et al. 2014), azaz az egyes kaszkádszintek (1. ökoszisztémák állapota, 2. ökoszisztéma-szolgáltatás kapacitások, 3. ténylegesen igénybe vett szolgáltatások, 4. jóllét fenntartása vagy növelése) mentén halad. A kaszkád modell lényege, hogy az ökoszisztémák állapota a szolgáltatásnyújtó-képességen keresztül befolyásolja a ténylegesen igénybe vett szolgáltatások mennyiségét, ezáltal pedig a jóllét fenntartását vagy növelését (1. ábra).

Alapfeltevésünk szerint csak a megfelelö állapotban lévő ökoszisztémák (1. szint) képesek arra, hogy a szolgáltatások széles körét nyújtsák az emberiség szá- 


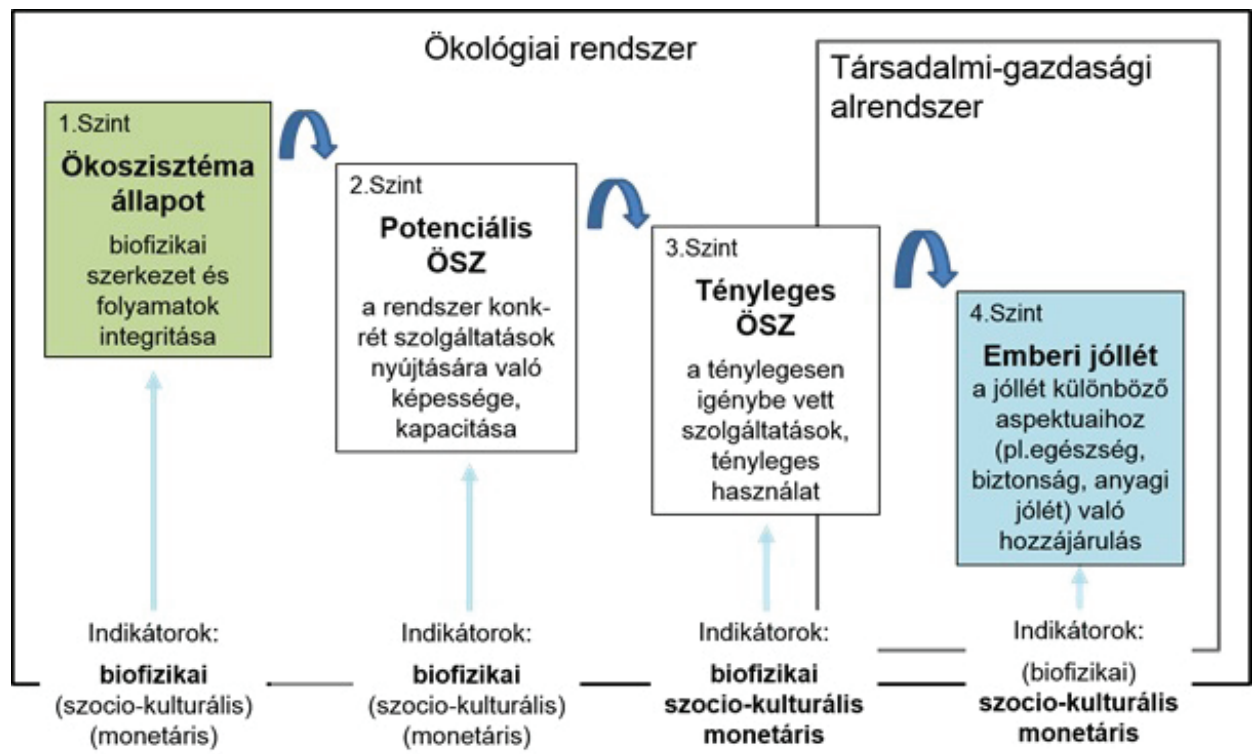

1. ábra: A NÖSZTÉP elvi háttere: a kaszkád keretrendszer (Haines-Young \& Potschin 2010, illetve Kovács et al. 2014, 2015 alapján, módosítva)

mára. Az ökoszisztéma állapot indikátora az adott ÖSz-től függően lehet a primer produkció vagy adott fajok, természetes élőhelyek jelenléte, elterjedése, a talaj termékenysége, vagy például városi környezetben a zöldfelületek aránya, területe. Az állapot (illetve több állapotjellemző együttesen) alapvetően meghatározza tehát az ÖSz-nyújtó képességét (ezt nevezhetjük ökoszisztéma funkciónak, potenciális ÖSz-nek vagy ÖSz-kapacitásnak; 2. szint). A ténylegesen igénybe vett ÖSz-eket (3. szint) azonban még sok tényező befolyásolhatja, pl. a társadalom igényei, lehetőségei, vagyis a kereslet jellemzői. Az igénybe vett ÖSz-ek a társadalom tagjai jóllétének fenntartásához vagy növekedéséhez (4. szint) járulnak hozzá (Kovács et al. 2014). Az értékelés báziséve minden kaszkádszinten 2015, melytől az adatok hozzáférhetősége alapján egyes esetekben eltérhetünk.

Mindegyik szinthez tartozhatnak biofizikai (biológiai, kémiai vagy fizikai egységeken alapuló), szocio-kulturális és pénzbeli indikátorok, melyek segítenek jellemezni, számszerüsíteni az adott szolgáltatásokat. A természeti rendszerhez tartozó ökoszisztémák állapotának és szolgáltatásnyújtó képességének értékelésében inkább a biofizikai, míg a jóllét megragadása során inkább a szocio-kulturális és monetáris indikátorok alkalmazása a jellemzőbb. A szocio-kulturális értékelés kvalitatív értékelést is magába foglal, ahol nem alkalmaznak indikátorokat, hanem fontos szolgáltatások vagy jólléti dimenziók kiválasztása és egyes esetekben rangsorolása történik. Az ökoszisztéma-szolgáltatások értékelésében mindegyik típus egyaránt fontos hangsúlyt kap. Az értékelés során az ökológiai és társadalmi 
rendszerek közötti rendszerhatár tudatos kezelésére törekszünk a tájhasználathoz, gazdasági tevékenységhez kötődő emberi inputok elkülönítésével. Továbbá egyes változókat alkalmazhatunk akár az ökológiai állapotot leíró szerepben, majd konkrétan az ÖSz-t meghatározó szerepben is. Számos szabályozó és fenntartó ÖSz esetében a 2. és 3. kaszkádszint, azaz a potenciális és aktuálisan felhasznált ÖSzek szintje, nem választható el élesen, vagy akár külön-külön nem is értelmezhető. Ebben a keretrendszerben jól elhelyezhetők a természetvédelem szempontjai (pl. a biodiverzitás, mint egy fontos ökoszisztéma-állapotjelző) és a tájhasználati tevékenységből remélt közvetlen hasznok egyaránt. Ez áttekinthetőbbé teheti ezek összetett viszonyrendszerét, ami segítheti a természetvédelmi érdekérvényesítést. Három ÖSz esetében (árvízi kockázat-csökkentés, éghajlat-szabályozás, gyalogos természetjárás) gazdasági értékelés is megvalósul.

Minden ÖSz-hez az 1., 2. és 3. kaszkádszinteken tervezetten térképi megjelenítés is társul, az Ökoszisztéma alaptérképre alapozva, a lehető legrészletesebb módon. Az alaptérkép kategóriái ÖSz-ektől függően akár összevonásra is kerülhetnek, ahol a legrészletesebb tematikus felbontás mellett az adott ÖSz nem értelmezhető, külön nem értékelhető (pl. a gyepek főkategóriájának használata a részletesebb gyepkategóriák helyett). A térbeli lépték meghatározása szintén ÖSz függő; legnagyobb ábrázolási felbontást az alaptérkép 20×20 méterben tesz lehetővé.

\section{Az értékelés ütemezése és további lépései}

Az értékelés időben négy ütemben, ütemenként a kaszkád-modell egy-egy szintjét feldolgozva halad. A projekt célja a teljes értékelés 2019 végéig/2020 elejéig való elkészítése. A projekt utolsó évében (2020) az egyes ÖSz-ek alapján végzett értékelésekre építve azok közti szinergiák és csereviszonyok (trade-off-ok), valamint potenciális jövőképek felvázolását tervezzük. Az elkészült értékelések és országos térképek remélhetőleg segítik majd a környezeti erőforrásokkal való fenntartható gazdálkodást, a zöld infrastruktúra hálózat fejlesztését, az egyes ágazatok közti hatékonyabb kommunikációt és a természetvédelmi döntéshozatalt.

Köszönetnyilvánitás - A fejlesztések az Európai Regionális Fejlesztési Alap (ERFA) finanszírozásával a Széchenyi 2020 részeként, a Környezeti és Energiahatékonysági Operatív Program, valamint a Versenyképes Közép-Magyarország Operatív Program kereteiben valósulnak meg (KEHOP-4.3.0-VEKOP-15-2016-00001). Kovács-Hostyánszki Anikót az NKFIH FK123813 projektje és az MTA Bolyai János Kutatási Ösztöndíj támogatta. A kézirat az Innovációs és Technológiai Minisztérium ÚNKP-19-4-SZIE-3 kódszámú Új Nemzeti Kiválóság Programjának szakmai támogatásával készült. 


\section{Irodalomjegyzék}

EC - European Commission (2013): Decision No 1386/2013/EU of the European Parliament and of the Council of 20 November 2013 on a General Union Environment Action Programme to 2020 'Living well, within the limits of our planet (http://eur-lex.europa.eu/legal-content/EN/ TXT/?uri=celex:32013D1386 - elérés: 2015. jún. 15.)

Haines-Young, R. \& Potschin, M. (2010): The links between biodiversity, ecosystem services and human well-being. - In: Raffaelli, D. G. \& Frid, C. L. J. (eds.): Ecosystem ecology: a new synthesis. Cambridge University Press, pp. 110-139.

Haines-Young, R. \& Potschin, M. (2013): Common International Classification of Ecosystem Services (CICES). - EEA Framework Contract No EEA/IEA/09/003.( http://www.cices.eu - elérés: 2019. jún. 15.)

Kelemen, E. (2013): Az ökoszisztéma szolgáltatások közösségi részvételen alapuló, ökológiai közgazdaságtani értékelése. - Doktori értekezés, Szent István Egyetem, Környezettudományi Doktori Iskola, Gödöllö.

Kovács, E. (2014): Az ökoszisztéma-szolgáltatások megjelenése a biodiverzitás politikában. - In: Kelemen, E. \& Pataki, Gy. (szerk.) Ökoszisztéma-szolgáltatások: A természet- és társadalomtudományok metszéspontjában. Szent István Egyetem, Környezet- és Tájgazdálkodási Intézet, Environmental Social Science Research Group (ESSRG), Gödöllö-Budapest, pp. 131-143.

Kovács, E., Harangozó, G., Marjainé Szerényi, Zs. \& Csépányi, P. (2015): Natura 2000 erdők közgazdasági környezetének elemzése. - Duna-Ipoly Nemzeti Park Igazgatóság, Esztergom, 217 p.

Kovács, E., Kelemen, E. \& Czúcz, B. (2014): A természettől a jóllétig: az ökoszisztéma-szolgáltatások természet- és társadalomtudományi meghatározottsága. - In: Kelemen, E. \& Pataki, Gy. (szerk.) Ökoszisztéma-szolgáltatások: A természet- és társadalomtudományok metszéspontjában. Szent István Egyetem, Környezet- és Tájgazdálkodási Intézet, Environmental Social Science Research Group (ESSRG), Gödöllö-Budapest, pp. 15-34.

Maes, J., Teller, A., Erhard, M., Liquete, C., Braat L., Berry, P., Egoh, B., Puydarrieux, P., Fiorina, C., Santos, F., Paracchini, M. L., Keune, H., Wittmer, H., Hauck, J., Fiala, I., Verburg, P.H., Condé, S., Schägner, J. P., San Miguel, J., Estreguil, C., Ostermann, O., Barredo, J.I., Pereira, H.M., Stott, A., Laporte, V., Meiner, A., Olah, B., Royo Gelabert, E., Spyropoulou, R., Petersen, J. E., Maguire, C., Zal, N., Achilleos, E., Rubin, A., Ledoux, L., Brown, C., Raes, C., Jacobs, S., Vandewalle, M., Connor, D., \& Bidoglio. G. (2013): Mapping and Assessment of Ecosystems and their Services. An analytical framework for ecdosystem assessments under action 5 of the EU biodiversity strategy to 2020. - Publication office of the European Union, Luxembourg, $57 \mathrm{p}$.

Maes, J., Teller, A., Erhard, M., Murphy, P., Paracchini, M. L., Barredo, J. I., Grizzetti, B., Cardoso, A., Somma, F., Petersen, J. E., Meiner, A., Royo Gelabert, E., Zal, N., Kristensen, P., Bastrup-Birk, A., Biala, K., Romao, C., Piroddi, C., Egoh, B., Fiorina, C., Santos, F., Naruševičius, V., Verboven, J., Pereira, H., Bengtsson, J., Gocheva, K., Marta-Pedroso, C., Snäll, T., Estreguil, C., San Miguel, J., Braat, L., Grêt-Regamey, A., Perez-Soba, M., Degeorges, P., Beaufaron, G., Lillebø, A., Abdul Malak, D., Liquete, C.,Condé, S., Moen, J., Östergård, H., Czúcz, B., Drakou, E. G., Zulian, G. \& Lavalle, C. (2014): Mapping and Assessment of Ecosystems and their Services. Indicators for ecosystem assessments under Action 5 of the EU Biodiversity Strategy to 2020. 2nd Report, - Publications office of the European Union, Luxembourg, $90 \mathrm{p}$.

Maes, J, Teller, A, Erhard, M., Grizzetti, B., Barredo, J. I., Paracchini, M. L, Condé, S., Somma, F., Orgiazzi, A., Jones, A., Zulian, A., Petersen, J. E., Marquardt, D., Kovacevic, V., Abdul Malak, D., Marin, A. I., Czúcz, B., Mauri, A., Loffler, P., Bastrup-Birk, A., Biala, K., Christiansen, T. \& Werner, B. (2018): Mapping and Assessment of Ecosystems and their Services: An analytical framework for ecosystem condition. - Publications office of the European Union, Luxembourg, $75 \mathrm{p}$.

MEA - Millennium Ecosystem Assessment (2003): Ecosystems and Human Well-being: A Framework for Assessment. - Island Press, Washington DC. 245 p. 
MEA - Millennium Ecosystem Assessment (2005): Ecosystems and Human Well-being: Synthesis. - World Resource Institute, Washington DC. 137 p.

Tanács, E., Belényesi, M., Lehoczki, R., Pataki, R., Petrik, O., Standovár, T., Pásztor, L., Laborczi A., Szatmári, G., Molnár, Zs., Bede-Fazekas, Á., Kisné Fodor, L., Varga, I., Zsembery, Z. \& Maucha, G. (2019): Országos, nagyfelbontású ökoszisztéma- alaptérkép: módszertan, validáció és felhasználási lehetőségek. - Termvéd Közlem. 25: 34-58. https://dx.doi.org/10.20332/tvkjnatconserv.2019.25.34

\title{
National mapping and assessment of ecosystem services - a countrywide program of nature conservation
}

\author{
Anikó Kovács-Hostyánszki ${ }^{1}$, Krisztina Bereczki ${ }^{1}$, Bálint Czúcz ${ }^{1}$, \\ Veronika Fabók ${ }^{1}$, Lívia Fodor ${ }^{2}$, Ágnes Kalóczkai ${ }^{1}$, Márton Kiss ${ }^{1,3}$, \\ Péter Koncz ${ }^{1,4}$, Eszter Kovács ${ }^{5}$, Rita Rezneki ${ }^{1,4}$, Eszter Tanács ${ }^{1}$, \\ Katalin Török ${ }^{1}$, Ágnes Vári ${ }^{1,6}$, Anikó Zölei ${ }^{1}$ and Zita Zsembery ${ }^{2}$ \\ ${ }^{1}$ Centre for Ecological Research, Institute of Ecology and Botany, \\ H-2163 Vácrátót, Alkotmány u. 2-4., Hungary \\ ${ }^{2}$ Ministry of Agriculture, Department of Nature Conservation, \\ H-1055 Budapest, Kossuth Lajos tér 11., Hungary \\ ${ }^{3}$ Department of Climatology and Landscape Ecology, University of Szeged, \\ H-6722 Szeged, Egyetem u. 2., Hungary \\ ${ }^{4}$ Duna-Ipoly National Park Directorate, H-1121 Budapest, Költö u 21., Hungary \\ ${ }^{5}$ Szent István University, Institute of Nature Conservation and Landscape Management, \\ H-2100 Gödöllö, Páter Károly u. 1., Hungary \\ ${ }^{6}$ Centre for Ecological Research, GINOP Sustainable Ecosystems Group, \\ H-8237 Tihany, Klebelsberg Kuno u. 3., Hungary

\section{E-mail: kovacs.aniko@okologia.mta.hu}

One of the main goals of the EU Biodiversity Strategy 2020 is to maintain and restore ecosystem services. It requires the member states to assess and map the condition of ecosystems, and the state and economic value of the most important ecosystem services (ESs). Led by the Ministry of Agriculture an EU-co-financed KEHOP-4.3.0-VEKOP-15-2016-00001 project started in Hungary in 2016 to fulfill these goals. The evaluation of the ecosystem services follows a so-called cascade model, which has 4 main levels: 1 . condition of ecosystems, 2. capacity of ecosystems to provide selected ESs (potential supply), 3. actual use of ESs, 4. contribution of ESs to human wellbeing. The results of the project will hopefully assist the sustainable management of environmental resources, the development of the green infrastructure network, improved communication between different sectors, and proper decision making in nature conservation and other related sectors.

Keywords: Biodiversity Strategy, capacity, cascade model, ecosystem condition, green infrastructure, MAES, sustainable management, wellbeing 